\title{
Yield Loss in Cereals, Caused by Fusarium culmorum and F. pseudograminearum, Is Related to Fungal DNA in Soil Prior to Planting, Rainfall, and Cereal Type
}

G. J. Hollaway, Biosciences Research Division, Department of Environment \& Primary Industries, Horsham, 3401, Victoria, Australia; and M. L. Evans, H. Wallwork, C. B. Dyson, and A. C. McKay, South Australian Research and Development Institute, Adelaide, 5001, South Australia, Australia

\begin{abstract}
Hollaway, G. J., Evans, M. L., Wallwork, H., Dyson, C. B., and McKay, A. C. 2013. Yield loss in cereals, caused by Fusarium culmorum and F. pseudograminearum, is related to fungal DNA in soil prior to planting, rainfall, and cereal type. Plant Dis. 97:977-982.

In southeastern Australia, Fusarium crown rot, caused by Fusarium culmorum or F. pseudograminearum, is an increasingly important disease of cereals. Because in-crop control options are limited, it is important for growers to know prior to planting which fields are at risk of yield loss from crown rot. Understanding the relationships between crown rot inoculum and yield loss would assist in assessing the risk of yield loss from crown rot in fields prior to planting. Thirty-five data sets from crown rot management experiments conducted in the states of South Australia and Victoria during the years 2005 to 2010 were examined. Relationships between Fusarium spp. DNA concentrations (inoculum) in soil samples taken prior to planting and disease development and grain yield were evaluated in seasons with contrasting seasonal rainfall. F. culmorum and F. pseudograminearum DNA concen-

crown rot expression (stem browning and whiteheads) and negatively related to grain yield of durum wheat, bread wheat, and barley. Losses from crown rot were greatest when rainfall during September and October (crop maturation) was below the long-term average. Losses from crown rot were greater in durum wheat than bread wheat and least in barley. Yield losses from $F$. pseudograminearum were similar to yield losses from $F$. culmorum. Yield loss patterns were consistent across experiments and between states; therefore, it is reasonable to expect that similar relationships will occur over broad geographic areas. This suggests that quantitative polymerase chain reaction technology and soil sampling could be powerful tools for assessing crown rot inoculum concentrations prior to planting and predicting the risk of yield loss from crown rot wherever this disease is an issue.
\end{abstract} trations in soil prior to planting were found to be positively related to
Fusarium crown rot (FCR), caused predominantly by Fusarium pseudograminearum or F. culmorum, is a disease of small grain cereals, including bread wheat (Triticum aestivum), durum wheat (T. turgidum), barley (Hordeum vulgare), and oat (Avena sativa) $(2,4)$. FCR is an important disease in the eastern Australian grain belt $(2,6,10,14)$, North America $(17,24,26)$, Italy (22), and South Africa (16), among other locations (4).

Annual grain yield losses due to FCR in bread wheat have been estimated to be 2 to $3 \%$ in southeastern Australia and 5\% in northern Australia, with occasional damage as high as 20 and $89 \%$, respectively, reported in these two regions $(10,15,18)$. In the Pacific Northwest of the United States, Smiley et al. (23) reported average grain yield losses of $10 \%$, with losses as high as $35 \%$ observed.

Symptoms of FCR in cereals include brown discoloration of the lower stems (stem browning) and the formation of whiteheads in durum and bread wheat (27). Whitehead incidence and yield loss associated with FCR is exacerbated by moisture stress during grain fill $(4,7,10,15,20,23)$. Hollaway and Exell (10) observed that low September and October rainfall influenced severity of whitehead expression due to FCR in southeastern Australia.

All winter grown cereals, and many grassy weeds, host the FCR pathogens and support inoculum carry over from one season to the next on infested residues (4). Non-grass crops, such as oilseeds and pulses, are regarded as poor hosts $(8,9,12,16)$. The widespread adoption of conservation farming practices-in particular, stubble retention-during the last 20 years has been implicated in the increased prevalence of this disease $(4,10)$.

Corresponding author: G. J. Hollaway,

E-mail: grant.hollaway@dpi.vic.gov.au

Accepted for publication 16 January 2013.

http://dx.doi.org/10.1094/PDIS-09-12-0867-RE

(C) 2013 The American Phytopathological Society
Managing FCR in-crop is difficult because, currently, there are neither chemical control options nor commercial cereal cultivars with adequate genetic resistance to FCR (4). Therefore, preplanting identification of fields at risk from FCR is critical for reducing short- and long-term yield losses from this disease. Backhouse (1) described a visual method based on disease incidence in and yield of a current cereal which can be used to predict the risk of grain yield loss from FCR in a following cereal crop. However, this method is less useful after a break from cereal because the magnitude of decrease in inoculum due to the break cannot be assessed.

Australian grain growers have access to the PreDicta B testing service which uses quantitative real-time polymerase chain reaction (qPCR) technology to determine DNA concentrations of a range of soilborne pathogens, including $F$. culmorum and $F$. pseudograminearum, prior to planting (19). This technology is used by growers to assess the risk of yield loss from soilborne diseases and is well suited to examining relationships between preplanting Fusarium spp. DNA concentrations, disease expression, and yield in cereals.

The objective of this study was to assess relationships between preplanting inoculum of $F$. pseudograminearum and $F$. culmorum and yield loss from FCR in bread wheat, durum wheat, and barley in southeastern Australia. This was done using qPCR to measure fungal inoculum DNA concentrations preplanting, followed by incrop assessment of FCR expression (browning of stem bases and whitehead formation) and cereal yield in seasons with contrasting rainfall in the states of South Australia and Victoria.

\section{Materials and Methods}

Thirty-five data sets, obtained from 13 field experiments in nine site-year combinations, were considered in this study (Table 1). Several of the experiments were designed to compare a range of preplanting FCR soilborne inoculum concentrations with grain yield of cereals. Other experiments were established to study aspects of crop sequencing, inter-row planting, and stubble treatments in relation to the management of FCR. The latter experi- 
ments had treatments that enabled comparisons between inoculum concentrations prior to planting and subsequent disease development and grain yield. In all cases, data were only taken from plots with similar histories (other than inoculum concentration) to ensure that comparisons were not confounded by variation in soil water or nutrient levels.

Experimental sites. Experiments were located in the southeastern Australian states of Victoria, at Longerenong $\left(36^{\circ} 40^{\prime} \mathrm{S}\right.$, $142^{\circ} 17^{\prime} \mathrm{E}$; gray cracking soil) and South Australia, at Cambrai $\left(34^{\circ} 38^{\prime} \mathrm{S}, 139^{\circ} 18^{\prime} \mathrm{E}\right.$; sandy loam soil) and Hart $\left(33^{\circ} 46^{\prime} \mathrm{S}, 138^{\circ} 26^{\prime} \mathrm{E}\right.$; friable light clay loam over carbonate). In these areas, cereal crops are sown following rain in the period April to June (autumn) and harvested November to December (late spring and early summer).

Sites were selected (using soil sampling and qPCR assays in a manner similar to that described in the next section) to have low or nondetectable concentrations of important soilborne diseases of cereals such as FCR, take-all (Gaeumannomyces graminis var. tritici), Rhizoctonia root rot (Rhizoctonia solani), and cereal cyst nematode (Heterodera avenae).

FCR inoculum was introduced to the sites by planting cereal seed inoculated with a macroconidia suspension $\left(10^{5}\right.$ spores $\left./ \mathrm{ml}\right)$ of either $F$. pseudograminearum or $F$. culmorum at a rate of $50 \mathrm{ml}$ per $1 \mathrm{~kg}$ of seed (8). The introduction of inoculum to the site occurred from 1 to 5 years prior to the year of study (Table 1 ).

Treatments imposed to manipulate inoculum densities, the histories, and cereal types for each field experiment are shown in Table 1. Experimental plot sizes were as follows: Longerenong, $8.5 \mathrm{~m}$ long by 6 rows wide; Cambrai, $24 \mathrm{~m}$ by 6 rows in 2005 and $12 \mathrm{~m}$ by 6 rows in 2007; Hart, 14 m by 6 rows. Row spacing was 170 $\mathrm{mm}$ at Longerenong, $180 \mathrm{~mm}$ at Cambrai, and $250 \mathrm{~mm}$ at Hart. Field experiments were direct seeded and managed according to local practice, including the appropriate use of herbicides to control weeds (no residual herbicides were used). All experiments were laid out in randomized blocks replicated six times, except for Hart in 2008 (H5-2008), which had four replicates.

Assessment of preplanting inoculum concentrations. The concentration of DNA of Fusarium spp. present in each plot (expressed as picograms of fungal DNA per gram of dry soil) was assessed prior to or at planting. Soil, including plant residues, was sampled using an Accucore sampler (Spurr Soil Probes) to a depth of $100 \mathrm{~mm}$ with a diameter of either $10 \mathrm{~mm}$ (Longerenong and Hart) or $15 \mathrm{~mm}$ (Cambrai). In all, 40 cores were taken from arbitrary points in each plot at Longerenong and Cambrai and 24 per plot at Hart. Within each plot, the samples were taken from the previous cereal row and included any plant residues that were retained with the sample. Soil from all cores in a plot was combined prior to analysis.

Soil samples were submitted to the Root Disease Testing Service at the South Australian Research and Development Institute (Adelaide) to assay for concentrations of DNA of $F$. pseudograminearum and $F$. culmorum. qPCR assays based on ribosomal DNA (TaqMan) probe sequences specific to $F$. pseudograminearum and $F$. culmorum were applied to the total DNA extracted from the whole oven-dried sample which, in general, weighed approximately 300 to $500 \mathrm{~g}$ before processing (18). Results were converted, using quantitative DNA standards, to picograms of $F$. pseudograminearum or $F$. culmorum DNA per gram of dry soil.

Disease assessments. The incidence of stems with stem browning was assessed at plant maturity, except for Cambrai 2005 and Hart in all years, where assessment was at early grain fill. At Longerenong, 30 arbitrarily selected stems were taken from each plot whereas, at Cambrai, 40 and 25 stems were arbitrarily selected in 2005 and 2007, respectively, for assessment. At Hart, stems were sampled from four $0.5-\mathrm{m}$ and four $0.25-\mathrm{m}$ row lengths in 2006 and 2008, respectively. Leaf sheaths were peeled back from each tiller or main stem and the basal node was inspected for the presence or absence of browning symptoms (27). Results were expressed as the percentage of stems with stem browning symptoms per plot.

The incidence of whiteheads was assessed in bread and durum wheat between anthesis (Z60) and maturity (Z91) $(6,14,28)$. Within each plot at Longerenong, three 1-m row lengths of heads were inspected. At Cambrai and Hart, heads were inspected on the plants collected for assessment of the incidence of stem browning as described above. Results were expressed as the percentage of whiteheads per plot.

Grain yield. At plant maturity, using a plot harvester, grain weight was recorded from each plot. Weights were converted to metric tons per hectare prior to analysis.

Rainfall data. Rainfall data for the previous 123 years for Longerenong, Hart (records at Blyth, approximately $10 \mathrm{~km}$ away), and Cambrai were obtained from SILO (www.longpaddock.qld. gov.au/silo), a digest of historic climate data (11). The combined September and October rainfall for each field experiment in the year of study is presented as a percentage of the average long-term combined September and October rainfall for the site.

Statistical analysis. Data sets were excluded from analysis if the site mean yield was less than 0.4 t/ha (i.e., severely drought-

Table 1. Details of Victorian and South Australian field experiments used to assess the relationships of preplanting soil concentrations of DNA of Fusarium pseudograminearum $(F p)$ and $F$. culmorum $(F c)$ on crown rot symptom expression and yield of barley, bread wheat, and durum wheat

\begin{tabular}{|c|c|c|c|c|c|c|}
\hline \multicolumn{6}{|l|}{ This study ${ }^{\mathrm{a}}$} & \multirow[b]{2}{*}{ History and methods of establishing Fusarium spp. levels } \\
\hline Experiment, year & Species & Year & Barley & Bread wheat & Durum wheat & \\
\hline \multicolumn{7}{|c|}{ Cambrai, South Australia } \\
\hline C1-2005 & $F p$ & 2005 & - & - & $\mathrm{X}$ & 2004 canola; 2003 range of crops; 2002 inoculated durum wheat \\
\hline C2-2007 & $F p$ & 2007 & - & - & $(\mathrm{X})$ & $\begin{array}{l}2006 \text { vetch; } 2005 \text { cereal types; } 2004-2002 \text { as for experiment } \\
\text { C1-2005 }\end{array}$ \\
\hline \multicolumn{7}{|c|}{ Hart, South Australia } \\
\hline H3-2006 & $F p$ & 2006 & $(\mathrm{X})$ & $\mathrm{X}$ & $(\mathrm{X})$ & $2005 \pm$ inoculated durum wheat \\
\hline H4-2008 & $F p$ & 2008 & - & - & $\mathrm{X}$ & 2007 field pea; 2006 cereals; $2005 \pm$ inoculated durum wheat \\
\hline H5-2008 & $F p$ & 2008 & - & - & $\mathrm{X}$ & 2007 field pea; 2006 cereals; $2005 \pm$ inoculated durum wheat \\
\hline H6-2009 & $F p$ & 2009 & $\mathrm{X}$ & $\mathrm{X}$ & $\mathrm{X}$ & $\begin{array}{l}2008 \text { durum; } 2007 \text { field pea; } 2006 \text { cereals; } 2005 \pm \text { inoculated } \\
\text { durum wheat }\end{array}$ \\
\hline \multicolumn{7}{|r|}{ 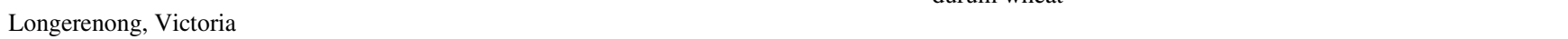 } \\
\hline L4-2007 & Fc & 2007 & - & $\mathrm{X}$ & $\mathrm{X}$ & 2006 field pea; $2005 \pm$ inoculated durum wheat \\
\hline L5-2007 & $F p, F c$ & 2007 & - & $\mathrm{X}$ & $\mathrm{X}$ & 2006 field pea; $2005 \pm$ inoculated durum wheat \\
\hline L7-2009 & $F p, F c$ & 2009 & - & $\mathrm{X}$ & $\mathrm{X}$ & 2008 field pea; $2007 \pm$ inoculated durum wheat \\
\hline L8-2009 & $F p, F c$ & 2009 & - & $(\mathrm{X})$ & $\mathrm{X}$ & 2008 field pea; $2007 \pm$ inoculated durum wheat \\
\hline L9-2008 & $F p, F c^{\mathrm{b}}$ & 2008 & $\mathrm{X}$ & $\mathrm{X}$ & - & 2007 durum wheat sown with $0-100 \%$ seed infection \\
\hline L10-2009 & $F p, F c$ & 2009 & $\mathrm{X}$ & $\mathrm{X}$ & - & 2008 durum wheat sown with $0-100 \%$ seed infection \\
\hline L11-2010 & $F p$ & 2010 & $(\mathrm{X})$ & $\mathrm{X}$ & $(\mathrm{X})$ & 2009 durum wheat sown with $0-100 \%$ seed infection \\
\hline
\end{tabular}

${ }^{a}$ Symbols: $-=$ not present in this experiment, $\mathrm{X}=$ data set included in this study, and $(\mathrm{X})=$ data sets excluded from further analysis because preplanting difference of fungal DNA was $<50 \mathrm{pg} / \mathrm{g}$ of soil between lower and upper quartiles or average site yield was $<0.4 \mathrm{t} / \mathrm{ha}$.

${ }^{\mathrm{b}}$ Data sets for F. culmorum at this site excluded for the reasons given above. 
affected site) or the difference from the lower to the upper quartile of the preplanting concentrations of Fusarium spp. was DNA at less than $50 \mathrm{pg} / \mathrm{g}$ soil. The latter ensured that the range in concentrations of DNA of Fusarium spp. was large enough for disease incidence and yield loss relationships to be explored.

Fusarium spp. DNA concentrations were $\ln (x+$ half the smallest non-zero value) transformed, the incidence of stem browning (percent) and whiteheads (percent) were arcsine transformed (arcsine $\sqrt{[\% / 100]}$ ), and grain yields were square-root transformed to normalize data prior to analysis. Associations between preplanting inoculum concentrations and stem browning, whiteheads, and grain yield were then investigated using linear correlation (Pearson's correlation coefficient) in GenStat (14th edition). One-tailed $t$ values were used because it was reasonable to presume that relationships between preplanting inoculum concentrations and stem browning and whiteheads would be positive whereas relationships with grain yield would be negative. No significant relationships appeared to dispute this assumption.

DNA concentrations prior to sowing were compared with relative mean yield $(\%)$, where relative mean yield $(\%)=[($ plot yield $[\mathrm{t} / \mathrm{ha}] /$ average site yield $[\mathrm{t} / \mathrm{ha}]) \times 100]$. After establishing that these relationships were linear using scatter plots, simple linear regressions in GenStat v14 were used to determine the slopes of these relationships. Significant differences between the slopes were tested for using the $t$ test formula $\left(\beta_{1}-\beta_{2}\right) / \sqrt{ }\left[\left(\text { s.e. } \beta_{1}\right)^{2}+\left(\text { s.e. } \beta_{1}\right)^{2}\right]$, where $\beta$ is the slope of the line and s.e. $\beta$ is its standard error. Comparisons of slopes between cereal types were only made where the cereal types were present within the same site-season experiment. For regressions and slope comparisons, one-tailed $t$ values were used, where appropriate. Yield loss estimates associated with doubling of inoculum concentrations were calculated as yield loss $(\%)=0.301 \times$ the slope of the relationship between preplanting DNA and relative mean yield (\%).

\section{Results}

Rainfall. Combined September and October (Sep+Oct) rainfall in all site-season combinations (Table 2) was either between 12 and $34 \%$ of the long-term average (considerably below average) or between 113 and $200 \%$ of the long-term average (above average). Sep+Oct rainfall at Longerenong and Hart was below average in the seasons 2006 to 2008 and above average in the seasons 2009 and 2010. Sep+Oct rainfall at Cambrai was above average in 2008.

F. culmorum. Nine data sets were available for analysis, one for barley and four each for durum wheat and bread wheat (Table 1). Within each of these data sets, preplanting inoculum concentrations in the upper quartile were between three- and sixfold greater than the lower quartile concentrations (Table 2). Three data sets were excluded from further analysis due to insufficient range in the preplanting inoculum concentrations (data not shown).

All significant associations between preplanting inoculum concentrations and grain yield were negative and all occurred in seasons with below-average Sep+Oct rainfall (Table 2). All significant associations between preplanting inoculum concentrations and disease expression, as indicated by stem browning and whiteheads, were positive (Table 2). Significant associations for stem browning occurred only in seasons with below-average Sep+Oct rainfall; however, significant associations for whiteheads occurred in seasons with both above- and below-average Sep+Oct rainfall (Table 2). Significant associations between preplanting inoculum concentration and disease expression and significant associations between preplanting inoculum concentration and grain yield were not al-

Table 2. Effects of preplanting soil concentrations of DNA of Fusarium culmorum and F. pseudograminearum and rainfall on expression of crown rot symptoms (stem browning and whiteheads) and grain yield of barley, durum wheat, and bread wheat in Victoria and South Australia, 2005-2010

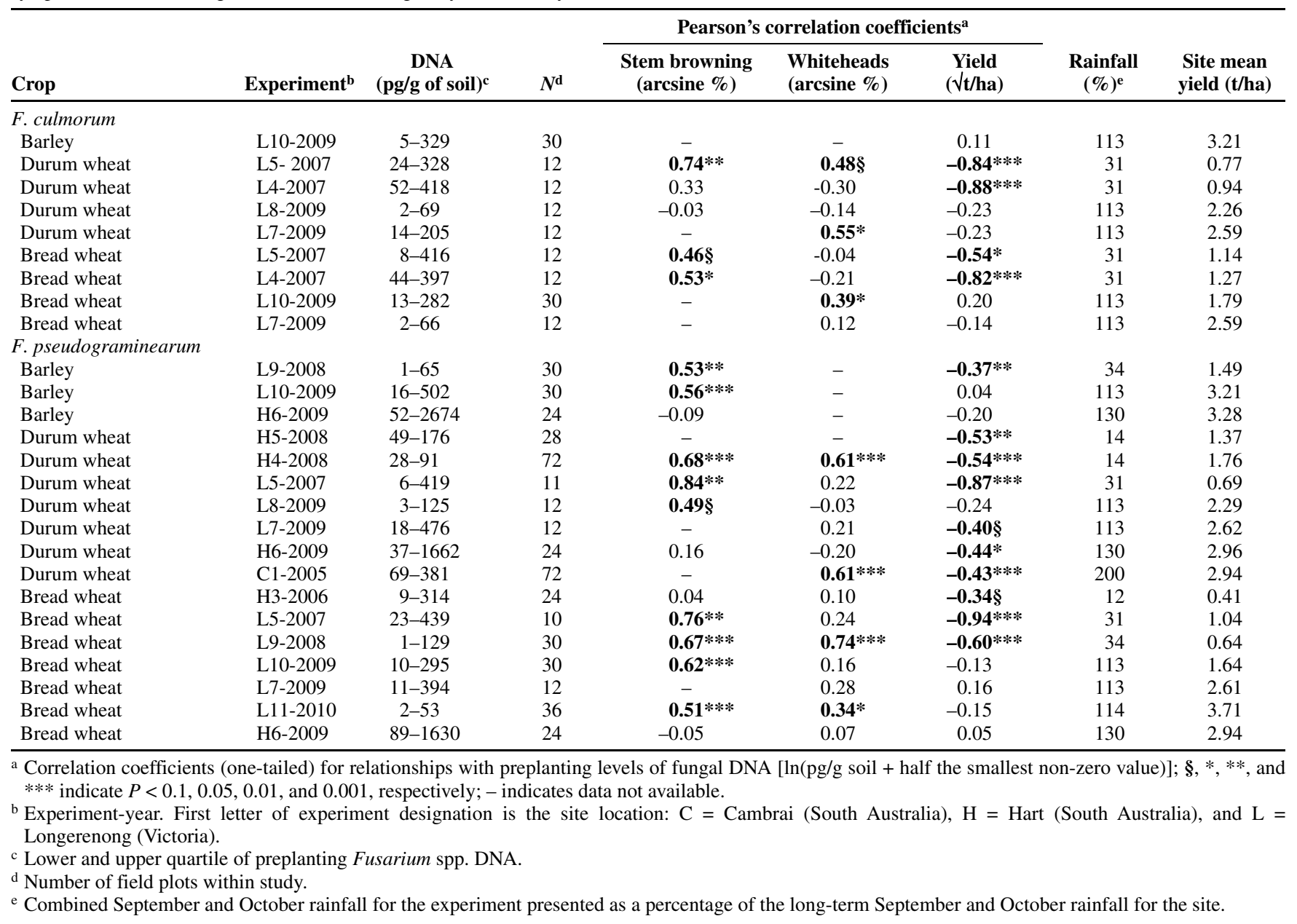


ways all present in the same experiments (c.f., durum wheat L42007 and bread wheat L10-2009; Table 2).

Grain yield decreased by 9 to $13 \%$ in durum wheat and 2 to $8 \%$ in bread wheat for each doubling of preplanting inoculum concentration in experiments with below-average Sep+Oct rainfall (Table 3). Comparison of slopes indicated that, for a given concentration of $F$. culmorum, the yield losses were greater for durum wheat than for bread wheat $(t$ was significant at $P=0.004$ in L52007 and $P=0.084$ in L4-2007). For these experiments, the preplanting inoculum concentrations explained more of the variation in relative mean yield for durum wheat (67 to 79\%) than for bread wheat (23 to 62\%) (Table 3). For experiments with above-average Sep+Oct rainfall, yield losses were very low (around 1\%) across all cereal types, and preplanting inoculum concentrations explained none of the variation in relative mean yield (Table 3 ).

F. pseudograminearum. Seventeen data sets were available for analysis: three data sets for barley and seven each for durum and bread wheat (Table 1). Within each of these data sets, preplanting inoculum concentrations in the upper quartile were twofold and up to sixfold greater than the lower quartile concentrations (Table 2). Three data sets were excluded from further analysis due to insufficient range in preplanting inoculum concentrations, and a further three data sets were excluded due to low site mean yield (data not shown).

All significant associations between preplanting inoculum concentrations and grain yield were negative. For barley and bread wheat, significant associations only occurred in seasons with below-average Sep+Oct rainfall (Table 2). For durum wheat, significant negative associations also occurred in all seasons with belowaverage and most seasons with above-average Sep+Oct rainfall
(Table 2). All significant associations between preplanting inoculum concentrations and disease incidence, as indicated by stem browning and whiteheads, were positive (Table 2). Significant associations between preplanting inoculum and disease expression and significant associations between preplanting inoculum and grain yield were not always present in the same experiments (c.f., bread wheat L11-2010 and L5-2007 and durum wheat H6-2009; Table 2).

Grain yield decreased by 6 to $8 \%$ in durum wheat, 2 to $9 \%$ in bread wheat, and $1 \%$ in barley for each doubling of preplanting inoculum concentration in experiments with below-average Sep+Oct rainfall (Table 3). Where Sep+Oct rainfall was below average, grain yield loss caused by a given concentration of $F$. pseudograminearum was similar in durum wheat and bread wheat ( $t$ was significant at $P=0.068$ in L5-2007) and was greater in bread wheat than barley ( $t$ was significant at $P=0.01$ in L9-2008). For durum wheat, yield loss caused by a given concentration of $F$. pseudograminearum was greater in seasons with below-average Sep+Oct rainfall than in seasons with above-average Sep+Oct rainfall ( $t$ was significant at $P<0.05$ ). Grain yield decreased minimally (0 to $3 \%)$ in all cereal types for each doubling of preplanting inoculum concentration in experiments with above-average Sep+Oct rainfall (Table 3).

For experiments with below-average Sep+Oct rainfall, preplanting inoculum concentrations explained more of the variation in relative mean yield for bread wheat (33 to 85\%) and durum wheat (23 to $74 \%$ ) than for barley (10\%) (Table 3). For experiments with above-average Sep+Oct rainfall, little of the variation in relative mean yield was explained by preplanting inoculum for durum wheat (up to $17 \%$ ) and none of the variation in relative mean yield was explained for bread wheat or barley (Table 3).

Table 3. Effects of preplanting soil concentrations of DNA of Fusarium culmorum and F. pseudograminearum and rainfall on the magnitude of rates of change in relative mean yield and the implications for comparative yield losses in barley, durum wheat, and bread wheat in Victoria and South Australia

\begin{tabular}{|c|c|c|c|c|c|c|c|c|c|}
\hline \multirow[b]{2}{*}{ Crop } & \multirow[b]{2}{*}{ Experiment $^{\text {b }}$} & \multicolumn{5}{|c|}{ Relationship of Fusarium spp. DNA with relative mean yield ${ }^{\text {a }}$} & \multirow[b]{2}{*}{$\operatorname{Loss}(\%)^{\mathrm{e}}$} & \multirow[b]{2}{*}{ Rainfall $(\%)^{\mathrm{f}}$} & \multirow[b]{2}{*}{ Yield (t/ha) ${ }^{g}$} \\
\hline & & Slope & s.e. Slope ${ }^{c}$ & $t$ Value & df & Variance $(\%)^{\mathrm{d}}$ & & & \\
\hline \multicolumn{10}{|l|}{ F. culmorum } \\
\hline Barley & L10-2009 & 0.94 & 1.65 & 0.57 & 28 & 0 & 0 & 113 & 3.21 \\
\hline Durum wheat & L5-2007 & $-24.8 * * *$ & 3.94 & -6.2 & 9 & 79 & 9 & 31 & 0.77 \\
\hline Durum wheat & L4-2007 & $-44.3 * * *$ & 9.92 & -4.78 & 10 & 67 & 13 & 31 & 0.94 \\
\hline Durum wheat & L8-2009 & -2.12 & 2.94 & -0.72 & 10 & 0 & 1 & 113 & 2.26 \\
\hline Durum wheat & L7-2009 & -2.8 & 3.96 & -0.71 & 10 & 0 & 1 & 113 & 2.59 \\
\hline Bread wheat & L5-2007 & $-6.5 *$ & 3.13 & -2.09 & 10 & 23 & 2 & 31 & 1.14 \\
\hline Bread wheat & L4-2007 & $-26.9 * * *$ & 6.23 & -4.32 & 10 & 62 & 8 & 31 & 1.27 \\
\hline Bread wheat & L10-2009 & 2.81 & 2.73 & 1.03 & 28 & 0 & 0 & 113 & 1.79 \\
\hline Bread wheat & L7-2009 & -1.87 & 4.21 & -0.44 & 10 & 0 & 1 & 113 & 2.59 \\
\hline \multicolumn{10}{|c|}{ F. pseudograminearum } \\
\hline Barley & L9-2008 & $-3.2 *$ & 1.57 & -2.09 & 28 & 10 & 1 & 34 & 1.49 \\
\hline Barley & L10-2009 & 0.28 & 1.23 & 0.22 & 28 & 0 & 0 & 113 & 3.21 \\
\hline Barley & H6-2009 & -1.21 & 1.22 & -0.99 & 22 & 0 & 0 & 130 & 3.28 \\
\hline Durum wheat & H5-2008 & $-24.1 * *$ & 7.95 & -3.03 & 26 & 23 & 7 & 14 & 1.37 \\
\hline Durum wheat & H4-2008 & $-26.4 * * *$ & 4.94 & -5.36 & 70 & 28 & 8 & 14 & 1.76 \\
\hline Durum wheat & L5-2007 & $-19.83 * * *$ & 3.65 & -5.43 & 9 & 74 & 6 & 31 & 0.69 \\
\hline Durum wheat & L8-2009 & -1.96 & 2.5 & -0.79 & 10 & 0 & 1 & 113 & 2.29 \\
\hline Durum wheat & L7-2009 & -3.82 & 2.81 & -1.36 & 10 & 7 & 1 & 113 & 2.62 \\
\hline Durum wheat & H6-2009 & $-4.25^{*}$ & 1.88 & -2.26 & 22 & 15 & 1 & 130 & 2.96 \\
\hline Durum wheat & C1-2005 & $-9.5 * * *$ & 2.41 & -3.96 & 69 & 17 & 3 & 200 & 2.94 \\
\hline Bread wheat & H3-2006 & $-5.85^{*}$ & 3.69 & -1.58 & 22 & 6 & 2 & 12 & 0.41 \\
\hline Bread wheat & L5-2007 & $-28.7 * * *$ & 3.90 & -7.36 & 10 & 85 & 9 & 31 & 1.04 \\
\hline Bread wheat & L9-2008 & $-10.7 * * *$ & 2.71 & -3.95 & 28 & 33 & 3 & 34 & 0.64 \\
\hline Bread wheat & L10-2009 & -2.09 & 2.75 & -0.76 & 28 & 0 & 1 & 113 & 1.64 \\
\hline Bread wheat & L7-2009 & 1.55 & 3.29 & 0.47 & 10 & 0 & 0 & 113 & 2.61 \\
\hline Bread wheat & L11-2010 & -2.68 & 3.27 & -0.82 & 34 & 0 & 1 & 114 & 3.71 \\
\hline Bread wheat & H6-2009 & 0.4 & 1.57 & 0.28 & 22 & 0 & 0 & 130 & 2.94 \\
\hline
\end{tabular}

${ }^{a}$ Relative mean yield $(\%)=$ (plot mean yield/average yield for the site $) \times 100$. Before regression analysis, data were examined to ensure the relationships were linear. *, **, and $* * *$ indicate $P$ values $<0.1,0.05,0.01$, and 0.001 , respectively, for a one-tailed test.

${ }^{\mathrm{b}}$ Experiment-year. First letter of experiment designation is the site location: $\mathrm{C}=$ Cambrai (South Australia), $\mathrm{H}=$ Hart (South Australia), and $\mathrm{L}=$ Longerenong (Victoria).

c Standard error (s.e.) slope.

${ }^{\mathrm{d}}$ Variance accounted for.

e Yield loss if soil DNA doubles.

${ }^{\mathrm{f}}$ Combined September and October rainfall for the experiment presented as a percentage of the long-term September and October rainfall for the site.

g Experiment-year mean yield. 
F. culmorum versus $\boldsymbol{F}$. pseudograminearum. Associations between preplanting inoculum concentrations and relative mean yield for the two Fusarium spp. could be compared in seven of the data sets (Table 3). For six comparisons (barley, L10-2009; durum wheat, L5-2007, L7-2009, and L8-2009; and bread wheat, L7-2009 and L10-2010) the slopes of the relationships were the same for both Fusarium spp. (t ns). Of these six comparisons, four data sets had above-average Sep+Oct rainfall, which may have masked differences between the Fusarium spp. For bread wheat in experiment L5-2007 (below-average Sep+Oct rainfall), the slope of the relationship was greater for $F$. pseudograminearum than for $F$. culmorum ( $t$ was significant at $P<0.01$ ), indicating greater losses from $F$. pseudograminearum than from $F$. culmorum.

\section{Discussion}

$F$. pseudograminearum and $F$. culmorum inoculum concentrations in soil prior to sowing, as measured by qPCR, were found to be positively related to FCR expression (stem browning and whiteheads) and negatively related to grain yield of durum wheat, bread wheat, and barley. Significant negative relationships between presowing inoculum concentrations and grain yield in bread wheat and barley were observed only in seasons where rainfall received during grain fill (Sep+Oct) was below the long-term average but not in those seasons where it was above average. For durum wheat, significant negative relationships with yield were observed in seasons when Sep+Oct rainfall was both above and below average but yield losses were less where Sep+Oct rainfall was above average. This is the first report in the literature which demonstrates relationships between Fusarium spp. DNA concentrations and yield for a range of cereal types.

The observation of greater losses from FCR in seasons with limited rainfall compared with seasons with above-average rainfall during grain fill was clear in this study and consistent with previous studies $(4,10,23,24)$. Using the data available; it was not possible to determine whether yield losses caused by different presowing concentrations of Fusarium spp. inoculum tapers as Sep+Oct rainfall increases or whether there is a sharp cut-off point at which yield loss no longer occurs. Further data sets are required from a wider range of seasons to better define and understand this relationship.

Regression analysis showed that preplanting inoculum concentrations of Fusarium spp. explained much of the variation in the yield of durum and bread wheat in seasons conducive to crown rot development. This supports the use of a presowing DNA-based soil test as a method for identifying FCR risk in a field prior to sowing. During seasons conducive to FCR, each doubling in presowing Fusarium spp. inoculum concentration reduced the yield of bread wheat, durum wheat, and barley by 2 to $9 \%, 6$ to $13 \%$, and $1 \%$ respectively. Within these studies, the low and high preplanting quartiles of fungal DNA generally was 23 to $474 \mathrm{pg} / \mathrm{g}$ of soil, representing a fourfold increase, which is consistent with observations from fields in southeastern Australia. This fourfold increase in preplanting inoculum concentrations corresponded to yield losses of 8 to $36 \%$ in bread wheat and 24 to $52 \%$ in durum wheat in seasons conducive to FCR within these studies. Other studies have reported similar yield loss from FCR $(10,15,18,23,25)$.

These studies showed that durum wheat was more sensitive to yield loss from FCR than bread wheat. Klein et al. (13) also noted the sensitivity of durum wheat to yield loss from FCR. Barley is widely considered less sensitive to FCR than bread wheat, based on general observation rather than on comparative yield data. This study showed barley to be less affected by FCR than bread wheat and suggests that it is probable that barley, under most circumstances, exhibits such small yield losses from FCR that any economic loss would be negligible.

No comparisons of the relative yield losses caused by $F$. pseudograminearum and $F$. culmorum have been reported in the literature. The limited data collected during this study suggest that similar yield losses were caused by both Fusarium spp. However, in one case, F. pseudograminearum caused higher yield loss than $F$. culmorum, and the reason for this difference was not clear. Although it seems reasonable to conclude that both Fusarium spp. cause similar yield losses, further studies are needed to determine whether the two species in mixed populations in the field interact and can affect cereal yield in a synergistic or antagonist way.

All significant associations between preplanting concentrations of Fusarium spp. inoculum and symptoms of FCR (stem browning or white heads) were positive, as to be expected. In seasons conducive to FCR development, significant associations between presowing inoculum concentration and stem browning and presowing inoculum concentration and white head incidence were observed in 80 and $33 \%$ of experiments, respectively. This suggests that whitehead severity may be a poorer indication of FCR severity in the field and is consistent with the observations of Smiley et al. (23).

The magnitude of potential yield losses associated with higher preplanting Fusarium spp. inoculum and the lack of in-crop control options emphasizes the importance of growers being able to assess the inoculum levels in their fields prior to sowing and relate that to the risk of yield loss. Once the risk is known, growers can make informed management decisions. If the risk is high, they can choose to reduce Fusarium spp. inoculum by implementing strategies such as rotation to nonhosts $(8,9,12,16)$ or stubble management (5). If the risk is moderate, growers may minimize risk by choosing barley over wheat. However, it must be remembered that barley can still carry over high inoculum loads into the next season (8), thus increasing the FCR risk in a subsequent cereal crop.

The findings from this study indicate that there is merit in cereal growers using a presowing DNA-based test to identify fields at risk of FCR. This is supported by the finding of consistent relationships in a range of environments and seasons in southeastern Australia. Roget (21) in Australia and Bithell et al. (3) in New Zealand have demonstrated that preplanting soil concentrations of DNA of $G$. graminis var. tritici can be used in forecasting the risk of disease of take-all in wheat. To further develop relationships between presowing inoculum concentrations and FCR risk, the relationships developed within this study need to be validated across a broader range of environments, seasons, and fields, and this is the subject of current studies.

\section{Acknowledgments}

This work was supported by the Grains Research and Development Corporation, the Victorian Department of Primary Industries, and the South Australian Research and Development Institute. We thanks G. Exell, G. Naglis, M. McLean, J. Alvarado, J. Bretag, I. Dumitrescu, A. Thomson, and R. Burns for their technical assistance; and J. Davidson and T. Bretag for their constructive comments on the manuscript.

\section{Literature Cited}

1. Backhouse, D. 2006. Forecasting the risk of crown rot between successive wheat crops. Aust. J. Exp. Agric. 46:1499-1506.

2. Backhouse, D., Abubakar, A. A., Burgess, L. W., Dennis, J. I., Hollaway, G. J., Wildermuth, G. B. , Wallwork, H., and Henry, F. J. 2004. Survey of Fusarium species associated with crown rot of wheat and barley in eastern Australia. Australas. Plant Pathol. 33:255-261.

3. Bithell, S. L., McKay, A. C., Butler, R. C., Herdina, Ophel Keller, K., Hartley, D., and Cromey, M. G. 2012. Predicting take-all severity in second-year wheat using soil DNA concentrations of Gaeumannomyces graminis var. tritici determined with qPCR. Plant Dis. 96:443-451.

4. Burgess, L. W., Backhouse, D., Summerell, B. A., and Swan, L. J. 2001 Crown rot of wheat. In: Fusarium Paul E. Nelson Memorial Symposium. B. A. Summerell, J. F. Leslie, D. Backhouse, W. L. Bryden, and L. W. Burgess, eds. American Phytopathological Society, St. Paul, MN.

5. Burgess, L. W., Backhouse, D., Swan, L. J., and Esdaile, R. J. 1996. Control of Fusarium crown rot of wheat by late stubble burning and rotation with sorghum. Australas. Plant Pathol. 25:229-233.

6. Burgess, L. W., Wearing, A. H., and Toussoun, T. A. 1975. Surveys of Fusaria associated with crown rot of wheat in eastern Australia. Aust. J. Agric. Res. 26:791-799.

7. Chekali, S., Gargouri, S., Paulitz, T., Nicol, J. M., Rezgui, M., and Nasraoui, B. 2011. Effects of Fusarium culmorum and water stress on durum wheat in Tunisia. Crop. Prot. 30:718-725.

8. Evans, M. L., Hollaway, G. J., Dennis, J. I., Correll, R., and Wallwork, H. 2010. Crops sequence as a tool for managing populations of Fusarium pseudograminearum and F. culmorum in south-eastern Australia. Australas. Plant Pathol. 39:376-382.

9. Felton, W. L., Marcellos, H., Alston, C., Martin, R. J., Backhouse, D., Bur- 
gess, L. W., and Herridge, D. F. 1998. Chickpea in wheat-based cropping systems of northern New South Wales II. Influence on biomass, grain yield, and crown rot in the following wheat crop. Aust. J. Agric. Res. 49:401-407.

10. Hollaway, G. J., and Exell, G. K. 2010. Survey of wheat crops for white heads caused by crown rot in Victoria, 1997-2009. Australas. Plant Pathol. 39:363-367.

11. Jeffrey, S. J., Carter, J. O., Moodie, K. B., and Beswick, A. R. 2001. Using spatial interpolation to construct a comprehensive archive of Australian climate data. Environ. Model. Software 16:309-330.

12. Kirkegaard, J. A., Simpfendorefer, S., Holland, J., Bambach, R., Moore, K. J., and Rebetzke, G. J. 2004. Effect of previous crops on crown rot and yield of durum and bread wheat in northern NSW. Aust. J. Agric. Res. 55:321-334.

13. Klein, T. A., Burgess, L. W., and Ellison, F. W. 1989. The incidence of crown rot in wheat, barley and triticale when sown on two dates. Aust. J. Exp. Agric. 29:559-563.

14. Klein, T. A., Burgess, L. W., and Ellison, F. W. 1990. Survey of the incidence of white heads in wheat crops grown in northern New South Wales, 1976-1981. Aust. J. Exp. Agric. 30:621-627.

15. Klein, T. A., Burgess, L. W., and Ellison, F. W. 1991. The incidence and spatial patterns of wheat plants infected by Fusarium graminearum Group 1 and the effect of crown rot on yield. Aust. J. Agric. Res. 42:399-407.

16. Lamprecht, S. C., Marasas, W. F. O., Hardy, M. B., and Calitz, F. J. 2006. Effect of crop rotation on crown rot and the incidence of Fusarium pseudograminearum in wheat in the Western Cape, South Africa. Australas. Plant Pathol. 35:419-426.

17. Moya-Elizondo, E. A., Rew, L. J., Jacobsen, B. J., Hogg, A. C., and Dyer, A. T. 2011. Distribution and prevalence of Fusarium crown rot and common root rot pathogens of wheat in Montana. Plant Dis. 95:1099-1108.
18. Murray, G. M., and Brennan, J. P. 2009. Estimating diseases losses to the Australian wheat industry. Australas. Plant Pathol. 38:558-570.

19. Ophel-Keller, K., McKay, A., Hartley, D., Herdina, and Curran. J. 2008 Development of a routine DNA-based testing service for soilborne diseases in Australia. Australas. Plant Pathol. 37:243-253.

20. Papendick, R. I., and Cook, R. J. 1974. Plant water stress and development of Fusarium foot rot in wheat subjected to different cultural practices. Phytopathology 64:358-363.

21. Roget, D. K. 2001. Prediction modelling of soilborne plant diseases. Australas. Plant Pathol. 30:86-89.

22. Rossi, V., Cervi, C., Chiusa, G., and Languasco, L. 1995. Fungi associated with foot rots on winter wheat in northwest Italy. J. Phytopathol. 143:115119.

23. Smiley, R. W., Gourlie, J. A., Easlye, S. A., Patterson, L.-M., and Whittaker, R. G. 2005. Crop damage estimates for crown rot of wheat and barley in the Pacific Northwest. Plant Dis. 89:595-604.

24. Smiley, R. W., and Patterson, L.-M. 1996. Pathogenic fungi associated with Fusarium foot rot of winter wheat in the semiarid Pacific Northwest. Plant Dis. 80:944-949.

25. Smiley, R. W., and Yan, H. 2009. Variability of Fusarium crown rot tolerances among cultivars of spring and winter wheat. Plant Dis. 93:954-961.

26. Strausbaugh, C. A., Bradley, C. A., Koehn, A. C., and Forster, R. L. 2004 Survey of root diseases of wheat and barley in southeastern Idaho. Can. J. Plant Pathol. 26:167-176.

27. Wallwork, H. 2000. Cereal root and crown diseases. GRDC, Kingston, ACT, Australia.

28. Zadoks, J. C., Chang, T. T., and Konzak, C. F. 1974. A decimal code for the growth stages of cereals. Weed Res. 14:415-421. 